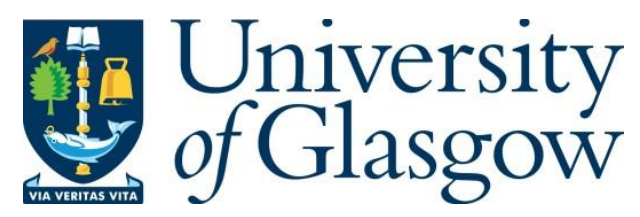

Dunmore, S. (2011) Xians via Yish? Language attitudes and cultural identities on Britain's Celtic periphery. Cornish Studies, 19(1), pp. 60-83.

There may be differences between this version and the published version. You are advised to consult the publisher's version if you wish to cite from it.

http://eprints.gla.ac.uk/205749/

Deposited on: 16 December 2019

Enlighten - Research publications by members of the University of Glasgow http://eprints.gla.ac.uk 


\title{
Xians-via-Yish?
}

\section{Language Attitudes and Cultural Identities on Britain's Celtic Periphery}

\author{
Stuart Dunmore
}

\begin{abstract}
Introduction
This paper is based on a study conducted in 2007 and examines the varying degrees to which the Welsh, Scottish Gaelic (henceforward 'Gaelic') and Cornish languages are regarded as symbols of minority identity in twenty-first century Britain. In order to quantify this tripartite comparison, questionnaires were used to measure the identities, language abilities and language attitudes of young people in full-time education at schools in Ceredigion, the western Highlands and west Cornwall. The first section of the article introduces the theoretical context and provides an analysis of existing literature on attitudes to Welsh, Gaelic and Cornish, and on the role of these 'Xish' minority languages in the expression of 'Xian' cultural identities in each context. The second section outlines the methodology employed and assesses the roles assigned to Welsh, Gaelic and Cornish in the construction of identities by students in each of the three locations.
\end{abstract}

In Reversing Language Shift, Joshua Fishman (1991) distinguishes between the threatened minority language (termed 'Xish') and the dominant, majority language ('Yish'). He advises that the ideological distinction between 'Xians' and 'Yians', and between Xish and Yish culture must be clarified early on in any attempt at language revitalisation, and warns that all efforts to reverse language shift "will be conflicted and contested from within" unless these clarifications are made at the onset of such initiatives. ${ }^{1}$ He further asserts that the establishment of a society committed to the ideal of 'Xians with Xish' is difficult to attain, particularly where "the phenomenon of Xmen-via-Yish has already taken root and proved itself to be rewarding". 
Language activists are engaged in reversing language shift (RLS) within three distinct Celtic language contexts in Great Britain. The expression of Xian identity via Yish is an experience common to each, with distinctive minority identities articulated by English-monoglot Welshmen, Highlanders and Cornishmen alike. Thus, the 'Xians-via-Yish' approach appears to be very deeply-rooted in the public psyche. This study uses questionnaires distributed in secondary schools in each context to examine the extent to which the Welsh, Gaelic and Cornish languages are still regarded as tokens of minority Xian identity in $21^{\text {st }}$ century Wales, Scotland and Cornwall.

\subsection{The language/ identity nexus: paradigms, approaches and conclusions}

In Fishmanite terms, language shift to 'Yish' in minority language contexts often effects the development of an 'Xian-via-Yish' identity, which is seen to undermine the premise that competence in 'Xish' is a vital and necessary precondition to the expression of Xian identity. ${ }^{3}$ The existence of this rival identity in contexts of language shift is seen to present one of the most obstinate obstacles to activists engaged in reversing language shift (RLS). Mari Jones affirms that a "crucial stage" of language decline is reached when an individual with no command of a given (Xish) language "could still be considered as a member of the [Xian] community" associated with it. ${ }^{4}$ This stage seems to have been reached in each of the contexts examined in this paper. Therefore the question in hand is the extent to which or the Welsh, Gaelic and Cornish languages retain a degree of symbolic importance in minority identity expression.

Language is often seen as an important dimension of identity negotiation, though not all scholars attribute as prominent a role to language in the construction of identity as does Fishman. ${ }^{5}$ The close association of language with identity formation and nation-building was an important aspect of the romantic nationalist movements of the $18^{\text {th }}$ and $19^{\text {th }}$ centuries. Philosophers such as Herder and Fichte depicted language as pre-eminent in their conception of nationhood, though Stephen May concludes that "linguistic nationalism" of this kind, which conceives of the nation as a natural and linguistically determined entity, is nowadays viewed as "little more than sociological (and linguistic) nonsense." 6 In any case, Herder and Fichte's conception of nationhood largely drew on and pertained to German-speaking populations on the 
European continent, rather than regional or minority language-speaking communities in the $21^{\text {st }}$ century. Yet while language is not seen as an "essential", "primordial" or "determining" feature of ethnic and national identity, May asserts that it remains "significant" in many instances and often has strongly felt associations with identity.

Language has been identified as an important token of regional or national identity in numerous sociolinguistic studies in recent years, while sociological and anthropological perspectives have also offered important insights into the nature of this relationship. ${ }^{8}$ At the same time, the role of language as a marker of identity is by no means unquestioned in modern social science, and Rogerson and Gloyer suggest that the role of language as an indicator of cultural identity (at least in the instance of Scottish Gaelic) needs to be reassessed. ${ }^{9}$ It "should not be assumed" therefore, that cultural identity is predicated on language, and while language is sometimes seen as central to a particular identity, this situation is by no means inevitable. ${ }^{10}$ Rachel Hoare suggests that the relationship between ethnicity and language is often one of association rather than actual use or competence, a view also propounded by Cole and Williams. ${ }^{11}$ Similarly, May avers that where language is considered crucial to identity, it is the "diacritical significance attached to language... not the actual language itself" that is regarded as essential (emphasis in original). ${ }^{12}$ It is in this sense that the Gaelic and Cornish languages might be expected to retain a role in the formation of minority identities.

Colin Williams identifies language as "one of the chief components of group identity" and argues that as such, it has come to be seen as "one of the most sensitive issues of the contemporary world." ${ }^{13}$ Yet he goes on to assert that "no necessary correspondence exists between linguistic reproduction and ethnic/immigrant identity", and that "manifestations of identity often continue long after a group's language declines". ${ }^{14}$ Jones agrees with Williams in stating that the death of a language will not necessarily entail the death of the ethnicity with which it has traditionally been associated. ${ }^{15}$ To Eastman, language and identity are complex but discrete and separate structures, and she avows that "there is no one-to-one correspondence between language and ethnic identity". Where there is an association between ethnic identity and a particular language, knowledge of the language is often not considered necessary to the expression of that identity. Ethnic identity, unlike linguistic knowledge, "only develops once cultural differentiation takes place", and as such, represents an altogether different kind of "social fact" to language. ${ }^{16}$ 
The identity-language link is therefore seen to be far from straightforward, and various academics have questioned the significance of such a connection. Yet even in the Gaelic and Cornish contexts, where language shift is much further advanced (to different degrees) than in Wales, it does not seem impossible that individuals might associate with the language in question in negotiating questions of regional and national identity. The objective of the present study is therefore to delineate the extent to which Welsh, Gaelic and Cornish are regarded as components of Xian identities in Wales, Scotland and Cornwall.

\subsection{The role of the Welsh language in Welsh identity}

As a medium of business in the bilingual National Assembly of Wales and talisman of distinctive national identity, Welsh is often regarded as the best placed of the Celtic languages in demographic and sociolinguistic terms. Carwyn Fowler identifies the Welsh language as the sole medium by which Welsh identity was maintained after the Acts of Union of 1536 and 1542, and as an important contributory factor to the development of modern Welsh identity. ${ }^{17}$ Movements such as Plaid Cymru have placed language at the heart of their vision of a distinctive Welsh culture, and founding member Saunders Lewis asserted in 1962 that "the language is more important than self-government" in his celebrated radio address Tynged yr Iaith. ${ }^{18}$

R.O. Jones describes how attitudes to the language were drastically changed during the 1960s, a time he regards as one of "linguistic reawakening" that coincided with initiatives linked to the Western 'Ethnic Revival'. Jones highlights the work of the Welsh Language Society (Cymdeithas yr Iaith Gymraeg) in transforming attitudes to Welsh. ${ }^{19}$ Lyon and Ellis uncovered positive attitudes to the Welsh language among parents of children born on the strongly Welsh-speaking island of Anglesey in the late 1980s. Yet while it often argued that the Welsh language relies on a thriving Welsh culture for its continued survival, Lyon and Ellis conclude that the existence of many monolingual English-speakers who identify strongly with the Welsh culture shows that this culture per se is an insufficient medium for improving language prospects. ${ }^{20}$

As part of the 1992 'Euromosaic' survey, language attitudes were elicited from 293 Welsh speakers, of whom 86.4\% agreed and 8.9\% disagreed that "Wales would not really be Wales without Welsh speaking-people." 94.9\% agreed that it was "essential that children in Wales learn Welsh", while only $2.4 \%$ disagreed. $45.7 \%$ of Welsh speakers surveyed agreed that "there are more valuable languages to learn than 
Welsh", although almost as large a minority (41.3\%) disagreed. Thus opinion was found to be divided with regard to the value of Welsh in relation to other languages despite strong support for the language and its use across a diverse range of contexts. 93.5\% of informants self-identified as 'Welsh', 40.3\% as 'British', 25.3\% as 'European', and 5.5\% as 'English'. ${ }^{21}$ A 2001 survey conducted by Market Research Wales found that out of a sample of 1,008 Welshmen and -women, 83.8\% agreed with the proposition: "The Welsh Language is an important part of Welsh identity", with 14.9\% dissenting (cited in Cole \& Williams 2004. Where an element of compulsion or positive discrimination was introduced, however, as in the statement: "Certain jobs in Wales should be reserved to bilingual speakers", approval fell to $45.7 \%$ with $51.1 \%$ disagreeing, highlighting the importance of wording in language attitudes research (LAR) questions. Nevertheless, Cole and Williams conclude that the general acceptance of Welsh as a token of national identity is closely linked to increased normalisation of the language from the 1960s. ${ }^{22}$

Results presented by Cole (2006) show that out of a sample of 1008 people across Wales, 37\% self-identified as 'Welsh, not British' or 'More Welsh than British', and 28\% asserted that they were either 'More British than Welsh' or 'British, not Welsh' (with 35\% 'Equally Welsh and British'). The same study found a significant correlation between Welsh identity and views on devolution and independence, with a strong positive correlation (0.685) between Welsh identity and support for independence, and a negative correlation of -0.406 between Welsh identity and support for scrapping the assembly. Identity is acknowledged as the most significant independent variable in determining attitudes to devolution and independence, while language competency was a further factor in this; positive correlations were found between fluency in Welsh and support for independence or greater devolution. ${ }^{23}$

Newcombe asserts that "questions of identity are particularly complicated" in Wales since the dynamic between native speakers and learners of various backgrounds is a fluid and emotionally fraught one. ${ }^{24}$ Jones asserts that "for the majority of inhabitants, [Welsh] is no longer the central, unifying force in the community". Nor is it seen as the main hallmark of Welshness, but rather as one of a host of symbols (along with the Welsh national rugby team, flag, costume and culture) that promote "a feeling of Welsh ethnic distinctiveness". ${ }^{25}$ Nevertheless, even as only one of an array of tokens, the Welsh language continues to play an important role in 
definitions of Welsh identity and Williams avers that most inhabitants of Wales now accept "that bilingualism is a distinct feature of society" ${ }^{26}$ The link between language and nationalism has been considerably more robust in Wales than Scotland, and Williams describes how the relationship between "the Welsh language, national identity and Christianity" dominated the early policy formulations of Plaid Cymru. ${ }^{27}$ The Labour Party has largely adopted Saunders Lewis' principles in respect of the language's importance to Welsh nationhood.

May (2001) asserts that developments effecting the institutionalisation of Welsh over the last decade have helped to contribute to conceptions of the language "as an important (but not necessarily preeminent) component" of Welsh identity. ${ }^{28}$ Assembly Government attempts to stimulate a sense of public ownership of the language (see e.g. Iaith Pawb 2003) have generally met with a considerable degree of success. The roots of such initiatives reach far back into the last century however, and Stephen May (2000) traces the institutionalisation of the language from the foundation of the Welsh Office in 1964. This development was followed by the 1967 Welsh Language Act, the establishment of S4C in 1982, the 1988 Education Reform Act and 1993 Welsh Language Act, all of which May argues led to a reversal of the language's fortunes by the $1990 \mathrm{~s}^{29}$

A 1995 NOP survey of 815 individuals found widespread support for the language, with $75 \%$ of respondents in favour of equal status for Welsh and English and $88 \%$ 'proud' of the language. ${ }^{30}$ Nevertheless, a study of 494 student teachers found significant differences between the attitudes of native Welsh and English speakers. While 75.4\% overall agreed that "The Welsh language should be maintained because it is a sign of Welsh nationhood", differences emerged with regard to the statement: "Welsh is essential for participating fully in Welsh life", where although 39.3\% agreed overall (vs. 33\% against), 68.9\% - a significant majority - of Welsh speakers were found to agree while $49 \%$ of non-Welsh speakers disagreed. Where the element of compulsion with regard to Welsh-medium education was introduced, 50.5\% of Welsh speakers supported the proposition: "All pupils in Wales should be taught in Welsh", while $78.8 \%$ of non-Welsh speakers opposed it. ${ }^{31}$ Therefore, while generally positive attitudes to Welsh as a marker of identity are seen to prevail, May concludes that the antagonistic approach of some majority language speakers continues to militate against bilingual policy. ${ }^{32}$ 


\subsection{Gaelic identities in $21^{\text {st }}$ century Scotland}

A threshold question in relation to Gaelic is whether it should be understood as a language belonging to Scotland as a whole or only to part of the country (namely, the Highlands and Islands). This will determine exactly which group should be considered Xians in this context. MacKinnon points to rising numbers of Gaelic learners and increasing provision for the language (in education and the media) in arguing that the language provides a distinctive identity and unique tradition for the Scottish nation. ${ }^{33}$ This is seen as especially important in a globalising world, where bilingualism is regarded in many places as the only way to satisfy the need both to communicate internationally and yet maintain an individual social and linguistic identity.

Yet the feasibility of assigning such a role to the Gaelic language in defining Scottish nationhood is undermined by a complex array of socio-historical and political factors discussed by Glaser. ${ }^{34}$ Prominent among the issues raised is the extent of the mainstream public's unawareness of the Gaelic language, a phenomenon noted by Wilson McLeod. ${ }^{35}$ Tormod Caimbeul remarks that while it should not be over-stated, the historical antipathy of some Lowland Scots to Gaelic continues to play an important role in national attitudes to the language. ${ }^{36}$ Similarly, McLeod states that while to "over-emphasize either the frequency or importance of these attacks" would be a mistake, "abusive hostility" is a largely unstigmatized and frequently visible dimension of public discourse on Gaelic. ${ }^{37}$ Colin Williams explains that the Gaelic language in Scotland tends not to be seen as the national language in the same way that Irish is in Ireland, or Welsh is in Wales. ${ }^{38}$ In contrast to Wales, where the Welsh language has been a central tenet of Plaid Cymru's vision since the party's inception, McLeod avers that the "link between the Gaelic language and Scottish nationalism... is a weak one". 39

Given the SNP's past indifference to the Gaelic language therefore, Alex Salmond's 2007 Sabhal Mòr Ostaig lecture, in which he outlined his government's vision for the "long-term recovery of Gaelic across [Scotland]" was characterised by some remarkably strong rhetoric as to the language's place in Scottish identity. Salmond declared that "Gaelic remains central [and] fundamental to Scotland's identity, geography, history and cultural life" and insisted that "a vibrant Gaelic language and culture are central to what it means to be Scottish in the modern world." 
The SNP Government's ambition for the language was "to see Gaelic emerge again as a truly national language."

Yet to a considerable degree, support for Gaelic outside of the traditional heartland areas of the Gàidhealtachd has been hindered by the strong association of the language specifically with the Highlands and Islands. Within the 'Xians-via-Yish' paradigm therefore, the chief 'Xian' identity with which the Gaelic language has historically been linked is that of the Highlands. The 1992 'Euromosaic' study uncovered a clear tendency within the Gaelic-speaking community "to view Gaelic as a feature of a local identity." $72.3 \%$ of the 300 respondents self-identified as 'Gaels', while $65.3 \%$ reported a High to Medium affinity with an 'Islander' identity, and a lower proportion - 53.7\% - reported an affinity to a 'Highland' identity. This relatively weak feeling of Highland identity compares to $86.3 \%$ of respondents asserting a 'Scottish' identity, with smaller proportions feeling 'British' (41.7\%) and 'European' (28.3\%). 93.7\% of respondents agreed that "to keep their true identity the Highlands and Islands need their Gaelic speakers" while $76.7 \%$ agreed that it was "essential that children in the Highlands and Islands should learn Gaelic". However $45.0 \%$ of informants agreed that "To get on, there are more valuable languages to learn than Gaelic". The report concludes that the higher status afforded to other languages is "a measure of the low prestige of the language.",41

MacKinnon's 1981 survey of Scottish public opinion on Gaelic challenged the presupposition that the language is regarded with hostility by the majority of Scots outside of the Gàidhealtachd. ${ }^{42}$ Rather, MacKinnon highlights the moderately positive attitudes to the language he found to prevail in questions relating to the role of Gaelic in education, the media and public life generally. Support for the language was strongest in the Western Isles and lowest in the Lowlands, where attitudes became more positive with age. In terms of political allegiance, MacKinnon found nationalist voters to hold the most favourable attitudes to Gaelic, Tory voters the least. $^{43}$ Positive attitudes to Gaelic were also found in a 2003 BBC/MRUK poll, in which researchers conducted interviews with 1020 individuals throughout Scotland. Though $87 \%$ had no knowledge of Gaelic, a sizeable majority responded positively to questions relating to the promotion of Gaelic, with $87 \%$ agreeing that school pupils should be afforded the opportunity to learn the language (versus 3\% disagreeing) and $64 \%$ in favour of the proposition that bilingual and Gaelic-medium education should be promoted (versus $9 \%$ against). The finding that $66 \%$ of MRUK respondents agreed 
that "Gaelic is an important part of Scottish life and needs to be promoted" (versus 13\% against), suggests attitudes have changed considerably since the $1980 \mathrm{~s}^{44}$ By contrast, MacKinnon's 1981 survey found that a (slight) majority of respondents rejected the idea that "the Gaelic language is important for Scotland as a whole".

Changing attitudes over recent decades have been accompanied by the emergence of new lines of discourse regarding Gaelic's place in modern Scotland. James Oliver (2005) and Sharon Macdonald (1999) relate changing attitudes to the language since the 1960s to the reconceptualisation of Gaelic as a national language of Scotland. ${ }^{45}$ The Gaelic language has increasingly come to be seen as a marker of national identity, though this sense is not seen to approximate to a particularly strong association with Gaelic among a majority of Scots, or to a widespread determination to learn or use the language. ${ }^{46}$ Yet the gradual conceptual evolution of a 'Europe of the Peoples/Regions', is thought to have contributed to an increased awareness of minority identity generally, and impacted on the role of Gaelic in defining Scottishness. The work of language activists since the time of the aforementioned 'Ethnic Revival' is seen to have brought about a wider understanding of Gaelic is an 'unbounded' national language, no longer confined to the Gàidhealtachd or an illdefined sense of yesteryear. ${ }^{47}$

Gaeldom's own 'Ethnic Revival' (the 'Gaelic Renaissance') unfolded from bottom-up initiatives at the local level in the 1970s, and one result has been a dramatic increase in the number of Scots engaging with the language, whether through Gaelicmedium education in primary and secondary schools or in adult acquisition classes. ${ }^{48}$ Another consequence has been the 're-invention' of Gaelic as a source of cultural wealth available not only to the Gaels, but to Scots, Europeans and indeed to all of humanity. ${ }^{49}$ Williams concludes that "conventional interpretations... need to be recast as a result of the greater articulation of Gaelic identity as a national resource". 50

Yet it should be stressed that the language remains remote to many Scots across much of the country and is certainly not considered an exclusive or essential marker of Scottish identity by the majority. ${ }^{51}$ While the bounded, quasi-ethnic understanding of Gaelic as the language of the Highland Gael is seen to have weakened, with $45 \%$ of Gaelic speakers now living outwith the traditional heartland, ${ }^{52}$ the historic conception of the Highlands and Lowlands as distinct nations still persists in certain quarters. ${ }^{53}$ Konstanze Glaser outlines two discourses in identifying two distinct approaches to Gaelic identity, one based on a wider social conception drawing 
on community life within the traditional Gàidhealtachd, the other based on the language itself as an objectified marker of Scottish identity. ${ }^{54}$ Oliver defines this contrast in terms of Gemeinschaft and Gesellschaft, conceived in terms of 'community' and 'society'. He elaborates that the evolution of the Gesellschaft approach is inhibited by the persistent association of Gaelic with the 'traditional', and asserts that the language is more frequently perceived as a marker of a specifically Gaelic identity than of Scottish identity in a wider sense. ${ }^{55}$

Therefore the language's role as an identity marker is seen to be far from straightforward, and Gaelic has attracted learners from diverse ethno-cultural backgrounds. The hybrid nature of modern experiences of Gaelic is often treated with suspicion and scepticism in traditional (Gemeinschaft) contexts in the Highlands and Islands, while being seen as an advantage in the formation of emerging Gesellschaft identities in the 'Gàidhealtachdan ùra' ('new Gaidhealtachds'). ${ }^{56}$ At the same time some Anglophone Scots in both contexts have called into question the significance of the language to either the Scottish or Highland identities. ${ }^{57}$ It will be important in the coming years for Gaelic activists to investigate attitudes to Gaelic as a marker both of a uniquely Highland identity and of Scottish identity generally, and in this way to delineate the extent of the Xian-via-Yish phenomenon within the conceptually rich field of Scottish identities.

\subsection{Cornish as Xish, Cornish identity as Xian?}

The Cornish language occupies a disparate sociolinguistic space to that of either Gaelic or Welsh, having ceased to function as a living vernacular sometime in the late $18^{\text {th }}$ or early $19^{\text {th }}$ centuries. $^{58}$ 'Revived' varieties of the language were subsequently developed and adopted by enthusiasts in the late $19^{\text {th }}$ and early $20^{\text {th }}$ centuries. Philip Payton describes how the Cornish language revival "has been a puzzle and a problem" to academics in Celtic Studies, who have for the most part tended to conclude that the revival "has been a sham." ${ }^{59}$ While emphasising the distinctive situation of the language, Payton draws a parallel between the historical development of Gaelic and Cornish in asserting that both languages had lost all social and cultural status by the $18^{\text {th }}$ century, when Cornish was confined to the 'wild' western tip of the county and to the tongues of the poorest and least educated.$^{60}$

Kenneth MacKinnon's Independent Study of the Cornish Language ranks among the most influential works on the sociology of the language in recent years, 
and came to contribute in large part to the UK Government's decision to recognise Cornish under Part II of the European Charter for Regional or Minority Languages. MacKinnon suggests that the present number of speakers, learners and users of Cornish is very small (estimating little more than 1000 in total) and advises that consciousness-raising will be a vital exercise in the development of the language in coming years. ${ }^{61}$ Indeed, raising the profile of Cornish and "making the language more visible" is identified as a priority in 'Vision 3' of Cornwall County Council's 'Strategy for the Cornish Language'. 62

The 1980s saw a breakdown in consensus on how best to proceed with language revival, and Payton describes the bitterness with which issues of orthography have been contested in the two decades since, ${ }^{63}$ something which MacKinnon suggests appears, ironically, "to have had a stimulating effect upon public awareness of the language. ${ }^{, 64} \mathrm{He}$ identifies a new sense of optimism in the revival movement and describes the "new thinking" for Cornish that the turn of the century witnessed. ${ }^{65}$ The establishment of the Cornish Language Partnership ('Maga') in 2005 brought together a number of public and private bodies with "the aim of promoting Cornish and developing it further in Cornish life." ${ }^{.66}$ The different groups' agreement in 2008 on a single written form (thanks largely to the work of 'Maga') has set the revival on a new footing, with the 'SWF' now increasingly used as a standard for use in schools and public life.

The influence that the English language and nation exerted over Cornwall from the $8^{\text {th }}$ century onwards wrought enormous changes on the (socio)linguistics, demographics and society of the region. As English pushed its way down the southwestern peninsula, a distinctly Cornish English became established in the eastern half of Cornwall, while a more standard English gripped the western periphery at a later stage, after Cornish had declined in that area. Though phonological and syntactic influence was largely unidirectional (into Cornish), Cornish English had by the $18^{\text {th }}$ century come to be seen as a uniquely and characteristically 'Cornish' form of language in eastern and central districts. This dimension of the Xian-via-Yish paradigm presents less of a problem in contemporary Cornwall since the English dialect has declined under the influence of Standard English since that time. ${ }^{67}$

Mackinnon avows that the total number Cornish speakers is tiny and, as a consequence, the role of the language in the formation of Cornish identity is often uncertain; ${ }^{68}$ indeed it has not always been generally accepted that such a distinct 
cultural identity actually exists in Cornwall. Mari Jones, for example, insists that "Cornwall is not a nation and is not perceived as such by its people", and that Cornish identity should be understood to be equivalent to other regional English identities, such as that articulated by 'Geordies'. ${ }^{69}$ The problem in seeking to attribute a role to the Cornish language as a token of distinctive identity is that "between the twelfth and mid-eighteenth century there existed at least six different systems" of orthography, so that there was "no uniform variety to serve as an emblem of Cornish identity". ${ }^{70}$ By contrast, Philip Payton maintains that Cornish is increasingly seen "as a powerful symbol of separate identity" in modern Cornwall. ${ }^{71}$

While Cornwall is often felt, particularly by outsiders but also by some insiders, to "occupy the same conceptual space" as any other English county, to many individuals it is viewed as much more than this. ${ }^{72}$ Many learners of the language explicitly relate their motivations to the desire to express their identity; some of the learners MacKinnon spoke to as part of his Study explained that they were learning the language to emphasise that they were "not English", or to become "as Cornish as possible". ${ }^{73}$ Another study conducted among Cornish language supporters in 2005 found the language and identity nexus to be central to learners' motivations, one interviewee commenting that "you can't separate the two things". Another explained that learning the language afforded individuals in Cornwall "a sense of place, a sense of identity, a sense of what the place is about" 74

Modern Cornish identity is seen as "notoriously difficult to define". ${ }^{75}$ In the absence of a Cornish ethnicity option on the UK census, Willett's (2008) study on perceptions of Cornish identity offers a vital and illuminating set of data on the phenomenon. Of her sample of 150 respondents in 16 Cornish towns, $73 \%$ saw Cornwall as a unit that was "more than a county", comparable to Wales or Scotland. $59 \%$ felt themselves to be Cornish and $41 \%$ felt 'More Cornish than English', while for over a third of respondents the Cornish identity formed their primary national identity. Genealogy and family history were considered the chief criteria for 'being' Cornish, particularly among those who possessed such ties, while being born in the county was also held to be important. ${ }^{76}$ A majority of respondents to Willett's survey felt the Cornish and English identity to be mutually compatible, and the extent to which a distinctly Cornish (Xian) identity has survived in Cornwall, which, after all has now been governed as an English county for more than 1000 years, is therefore a crucial question. 


\subsection{Data collection}

Schoolchildren were chosen as informants for the present study. A precedent in the literature for basing LAR studies within the context of formal education reflects recognition that the attitudes of schoolchildren are vital in determining the future prospects of minority languages. ${ }^{77}$ The results are based on the responses of young people (aged 15-16) in compulsory state education. It was hoped in this way that a broadly socially representative dataset could be obtained, allowing comparisons to be made across the three contexts. The age-group in question corresponds to the final year of compulsory education in the United Kingdom (Year 11 in England and Wales; S4 in Scotland).

State secondary schools in west Wales, the western Highlands and Cornwall were contacted, and a number of questionnaires were despatched to students in each of the three schools that had agreed to take part in the survey. 164 completed forms were returned from the Welsh school ('School A'), while 133 were returned from the Highlands ('School B') and 121 were received from the Cornish school ('School C'). The 418 returned questionnaires were coded, processed and analysed using Spearman's rank order correlation to determine the strength and direction of relationships between the variables of identity, language ability and language attitudes in each context

\subsection{Strength of regional and national identities}

The first section of the survey asked participants to locate their affiliations to particular identities on a five-point scale, ranging from 1 ('Not at all'), to 2 ('Hardly'), 3 ('Slightly'), 4 ('Fairly') and 5 ('Very much so'). The most striking finding in Wales was the strength of 'British' identity and relative weakness of 'Welsh' identity at the Ceredigion school, with $52 \%$ of respondents identifying themselves as 'Very much' British, but only $21 \%$ feeling Welsh to the same degree (see figure 1 ). ${ }^{78}$ Furthermore $21 \%$ claimed not to feel Welsh at all. Similar proportions felt 'slightly' and 'fairly' Welsh, while six informants gave no response with regard to feeling Welsh. If we infer this last finding to indicate weak association with Welsh identity, the combined figure for ' 0 ' and ' 1 ' responses represents $24 \%$, constituting the largest proportion pertaining to the question of 'Welshness'. 
Figure 1: Bar chart for School A showing number of responses by strength of identity $(0=$ No response, $1=$ 'Not at all', $5=$ 'Very much so')

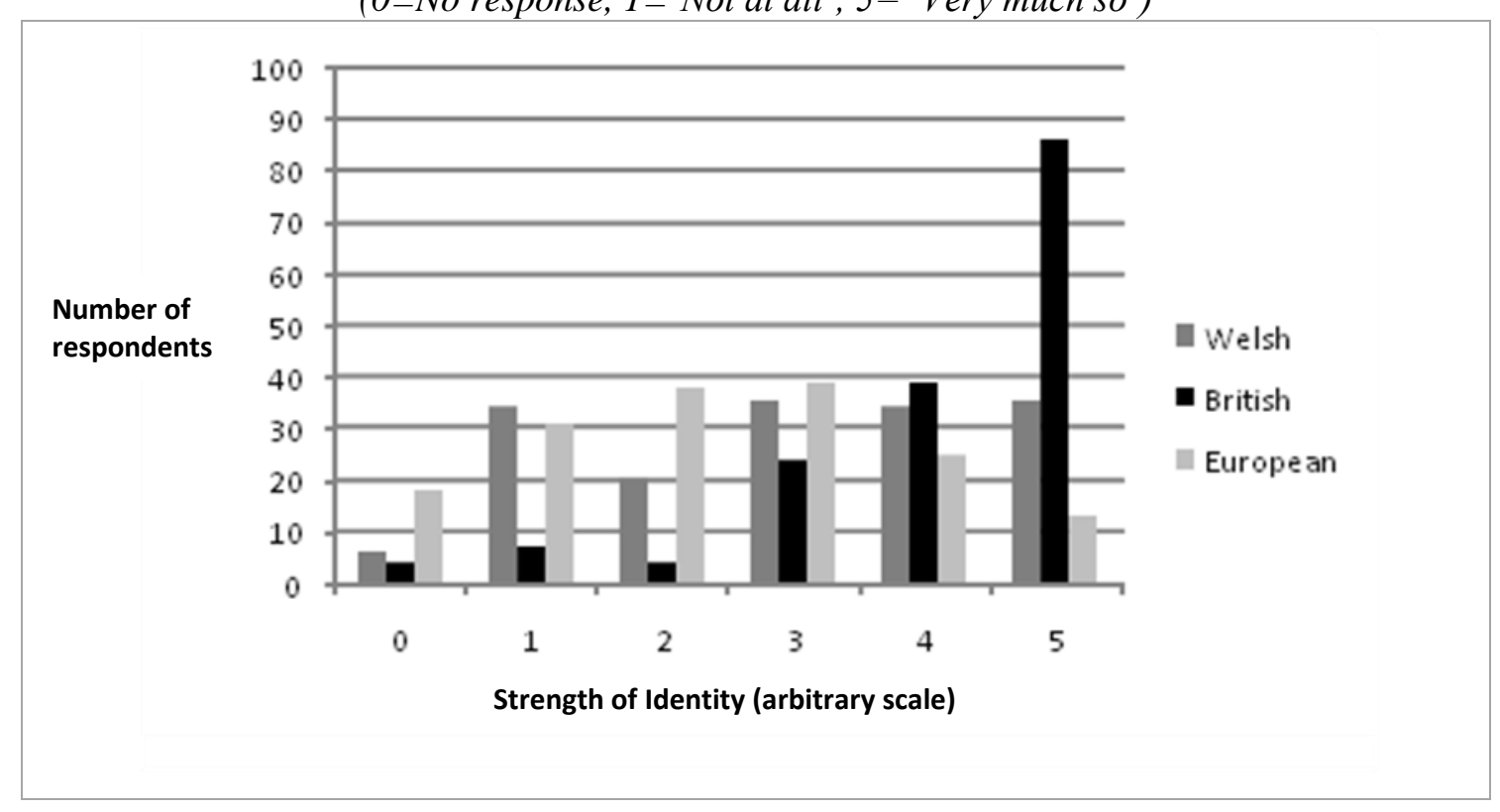

The strength of 'British' identity in relation to 'Welsh' was unexpected and runs contrary to findings outlined in section 1.2. Alasdair Cole's 2006 study, for instance, found only $22 \%$ of 1008 respondents across Wales felt "More British than Welsh", and only $6 \%$ who felt "British, not Welsh" ${ }^{79}$ By contrast, $21 \%$ of informants at School A indicated that they did not feel Welsh at all, and $4 \%$ gave no response. The weakness of Welsh identity among pupils at the Ceredigion school may reflect a dimension of demographics for which I had not accounted, specifically the proximity of the school to the University of Aberystwyth. It seems possible that a number of students at the school in question may come from in-migrant families drawn to the area from outside Wales, thereby accounting for the unexpected results.

In the Highlands, Scottish identity was found to be much stronger than Highland identity among S4 students surveyed, with $74 \%$ feeling themselves 'Very much' to be Scottish (figure 2, below). By comparison only $34 \%$ indicated that they felt themselves 'Very much' to be Highlanders. 29\% associated 'Fairly' strongly with Highland identity, though for $22 \%$ the association was only slight.

The relative weakness of the Highland identity compared with the Scottish identity broadly corresponds to findings from the 1994 Euromosaic survey (outlined in section 1.3 ), in which $53.7 \%$ of respondents asserted a 'Highland' identity and $86.3 \%$ of informants saw themselves as 'Scottish'. By comparison, 63\% of respondents at School B felt themselves to be 'Fairly' or 'Very much' Highlanders, while $90 \%$ felt 
Scottish to the same extent. Scottish pupils expressed a much weaker feeling of British identity than was true in Wales, although similar proportions of students at School B felt themselves to be 'Not at all' British (18\%), 'Hardly' British (20\%), 'Slightly' British (20\%), 'Fairly' British (19\%) and 'Very much' British (21\%).

Figure 2: Bar chart for School B showing number of responses by strength of identity $(0=$ No response, $1=$ 'Not at all', $5=$ 'Very much so')

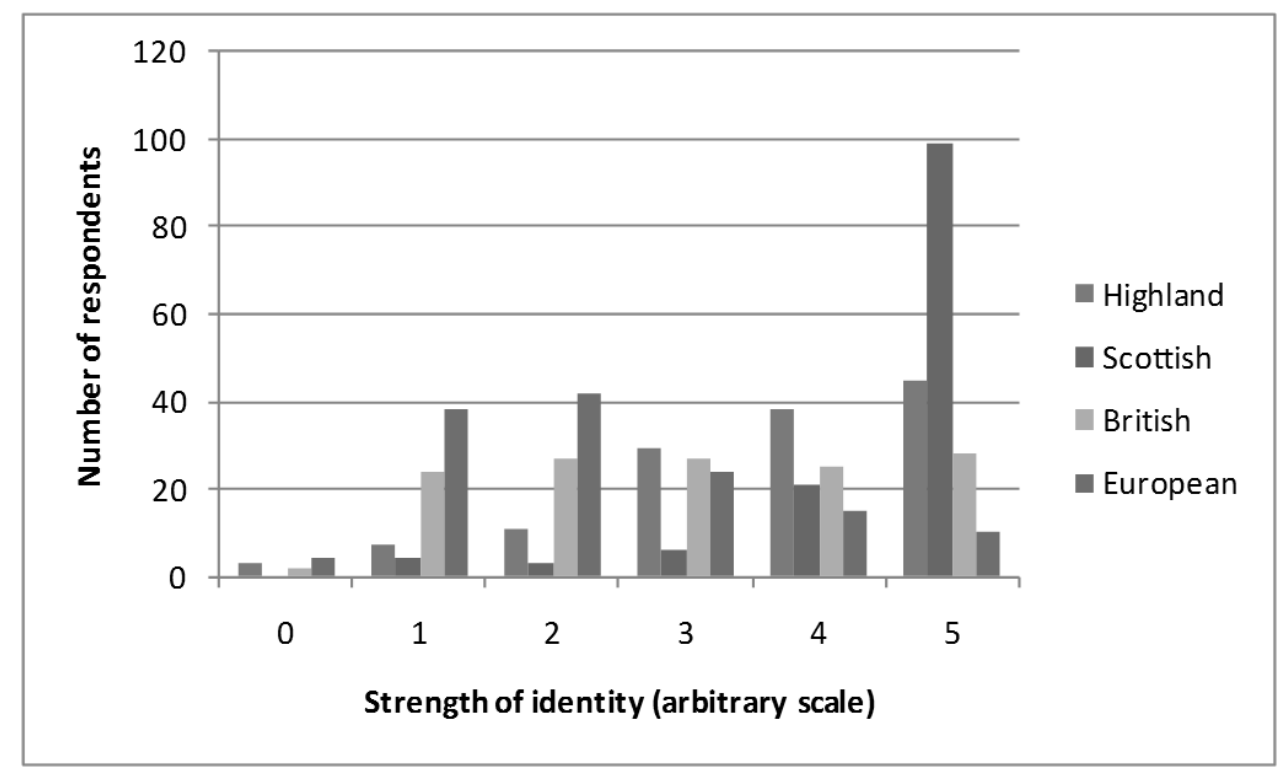

English identity was the most keenly felt among Year 11 pupils at School C in Cornwall, with $51 \%$ feeling themselves very much to be English and $40 \%$ feeling Cornish to the same extent, while $30 \%$ indicated that they felt very British (figure 3, below). 58\% felt themselves to be either 'Fairly' or 'Very much' Cornish, although a far larger proportion - 80\% - felt either 'Fairly' or 'Very much' English. This might reflect the degree of in-migration experienced in the second half of the twentieth century, although it is difficult to be sure of this given the scale and remit of the present study.

Nevertheless, the finding that a majority of respondents felt themselves to be either fairly or very Cornish suggests that a sense of Cornish identity remains reasonably strong among young people, even if it is clearly regarded as compatible with English identity. The findings described here therefore correlate closely with those presented by Willett (2008). 
Figure 3: Bar chart for School C showing number of responses by strength of identity $(0=$ No response, $1=$ 'Not at all', $5=$ 'Very much so')

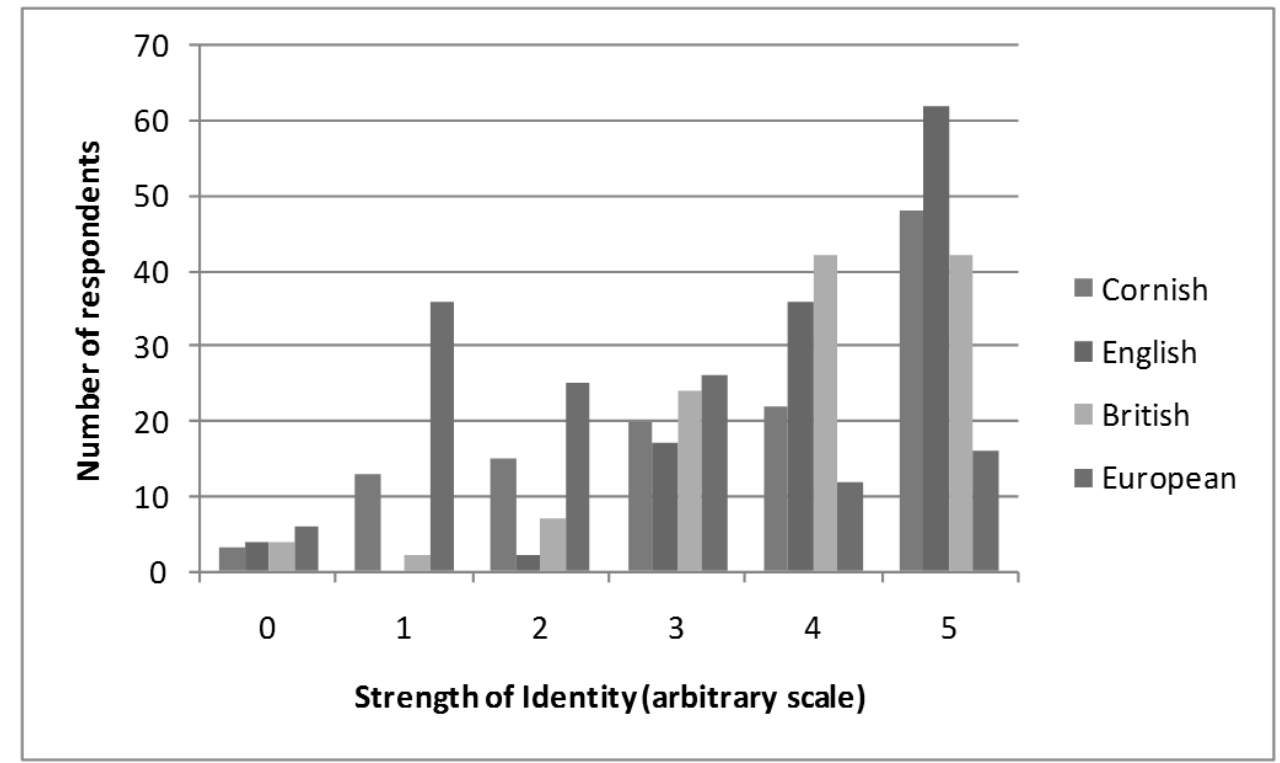

\subsection{Language attitudes and identity}

The second section of the survey elicited attitudinal data by asking informants to indicate the degree to which they agreed with three propositions regarding the role of the language as a marker of identity. In the case of the Gaelic questionnaire an extra statement ('proposition d)') was included in order to gauge the symbolic importance of Gaelic to the Highland identity as well as to the Scottish identity. Overall a significant majority - $68 \%$ of informants - at School A in Ceredigion agreed that 'Wales would lose its separate identity without the Welsh language', with only 17\% disagreeing (table 1, below).

By contrast, only 32\% of respondents at the Highland School B felt that Scotland as a whole would 'lose its separate identity' without Gaelic, while $43 \%$ disagreed. Half of respondents at School C in Cornwall agreed that 'Cornwall would lose its separate identity without the Cornish language', with only $32 \%$ dissenting. The proportion of unsure respondents was highest in the Highland context, with a quarter of students responding that they didn't know. It seems clear that while Welsh is considered a vital component of Welsh identity, and Cornish appears to be widely regarded as integral to Cornish identity, Gaelic is considered much less central to Scottish identity in the wider Gesellschaft sense, at least as regards this particular proposition. 
Table 1: Responses to proposition a)

\begin{tabular}{|l|l|l|l|l|l|l|}
\hline Proposition a) & $\begin{array}{l}\text { Strongly } \\
\text { agree } \\
\mathbf{\%}(\mathbf{N})\end{array}$ & $\begin{array}{l}\text { Agree } \\
\mathbf{\%}(\mathbf{N})\end{array}$ & $\begin{array}{l}\text { Disagree } \\
\mathbf{\%}(\mathbf{N})\end{array}$ & $\begin{array}{l}\text { Strongly } \\
\text { disagree } \\
\mathbf{\%}(\mathbf{N})\end{array}$ & $\begin{array}{l}\text { Don't } \\
\text { know } \\
\mathbf{\%}(\mathbf{N})\end{array}$ & $\begin{array}{l}\text { Total } \\
\mathbf{\%} \\
(\mathbf{N})\end{array}$ \\
\hline $\begin{array}{l}\text { "Wales would lose its separate identity } \\
\text { without the Welsh language." }\end{array}$ & $\begin{array}{l}22 \\
(37)\end{array}$ & $\begin{array}{l}46 \\
(75)\end{array}$ & $\begin{array}{l}13 \\
(22)\end{array}$ & $\begin{array}{l}4 \\
(6)\end{array}$ & $\begin{array}{l}15 \\
(24)\end{array}$ & $\begin{array}{l}100 \\
(164)\end{array}$ \\
\hline $\begin{array}{l}\text { "Scotland would lose its separate } \\
\text { identity without the Gaelic language." }\end{array}$ & $\begin{array}{l}12 \\
(16)\end{array}$ & $\begin{array}{l}20 \\
(26)\end{array}$ & $\begin{array}{l}30 \\
(40)\end{array}$ & $\begin{array}{l}13 \\
(18)\end{array}$ & $\begin{array}{l}25 \\
(33)\end{array}$ & $\begin{array}{l}100 \\
(133)\end{array}$ \\
\hline $\begin{array}{l}\text { "Cornwall would lose its separate } \\
\text { identity without the Cornish language." }\end{array}$ & $\begin{array}{l}15 \\
(18)\end{array}$ & $\begin{array}{l}35 \\
(42)\end{array}$ & $\begin{array}{l}23 \\
(28)\end{array}$ & $\begin{array}{l}9 \\
(11)\end{array}$ & $\begin{array}{l}18 \\
(22)\end{array}$ & $\begin{array}{l}100 \\
(121)\end{array}$ \\
\hline
\end{tabular}

$74 \%$ of students at the Ceredigion school agreed that 'Wales would not really be Wales without Welsh-speaking people', with 19\% disagreeing (Table 2, below). These proportions show a lesser degree of support for the Welsh language than that found in the Euromosaic survey, where $86.4 \%$ of native Welsh-speakers agreed and $8.9 \%$ disagreed with the same statement. A majority of students at School B (51\%) felt that Scotland would still be Scotland without any Gaelic-speakers, with only $32 \%$ agreeing that 'Scotland would not really be Scotland without Gaelic-speakers'. As with the first statement, a greater proportion of Cornish informants were found to agree with the second proposition than their Scots counterparts; 52\% agreed that 'Cornwall would not really be Cornwall' without Cornish-speakers. It is striking that only a third of Cornish students disagreed with proposition b), in spite of the tiny size of today's Cornish-speaking community.

Table 2: Responses to proposition b)

\begin{tabular}{|c|c|c|c|c|c|c|}
\hline Proposition b) & $\begin{array}{l}\text { Strongly } \\
\text { agree } \\
\%(\mathrm{~N})\end{array}$ & $\begin{array}{l}\text { Agree } \\
\%(\mathrm{~N}) \\
\end{array}$ & $\begin{array}{l}\text { Disagree } \\
\%(\mathrm{~N}) \\
\end{array}$ & $\begin{array}{l}\text { Strongly } \\
\text { disagree } \\
\%(\mathrm{~N})\end{array}$ & $\begin{array}{l}\text { Don't } \\
\text { know } \\
\%(N) \\
\end{array}$ & $\begin{array}{l}\text { Total } \\
\%(\mathrm{~N}) \\
\end{array}$ \\
\hline $\begin{array}{l}\text { "Wales would not really be Wales without } \\
\text { Welsh-speaking people." }\end{array}$ & $\begin{array}{l}23 \\
(38)\end{array}$ & $\begin{array}{l}51 \\
(83)\end{array}$ & $\begin{array}{l}13 \\
(22)\end{array}$ & $\begin{array}{l}6 \\
(10)\end{array}$ & $\begin{array}{l}7 \\
(11)\end{array}$ & $\begin{array}{l}100 \\
(164)\end{array}$ \\
\hline $\begin{array}{l}\text { "Scotland would not really be Scotland } \\
\text { without Gaelic-speaking people." }\end{array}$ & $\begin{array}{l}7 \\
(10)\end{array}$ & $\begin{array}{l}25 \\
(33)\end{array}$ & $\begin{array}{l}34 \\
(45)\end{array}$ & $\begin{array}{l}17 \\
(23)\end{array}$ & $\begin{array}{l}17 \\
(22)\end{array}$ & $\begin{array}{l}100 \\
(133)\end{array}$ \\
\hline $\begin{array}{l}\text { "Cornwall would not really be Cornwall } \\
\text { without Cornish-speaking people." }\end{array}$ & $\begin{array}{l}16 \\
(19)\end{array}$ & $\begin{array}{l}36 \\
(44)\end{array}$ & $\begin{array}{l}24 \\
(29)\end{array}$ & $\begin{array}{l}9 \\
(11)\end{array}$ & $\begin{array}{l}15 \\
(18)\end{array}$ & $\begin{array}{l}100 \\
(121)\end{array}$ \\
\hline
\end{tabular}

$72 \%$ of respondents in Wales agreed that 'the Welsh language is an important part of Welsh identity', with just $15 \%$ dissenting (Table 3, below). Support among the Ceredigion students for this statement, though still overwhelming, was therefore less 
than that found in 2001's Market Research Wales survey, in which $84 \%$ of respondents across the country agreed and $15 \%$ disagreed with the same statement. ${ }^{80}$

Gaelic was considered to be an important part of the Scottish identity by $47 \%$ of Highland informants (versus 36\% against), a higher proportion to that found in the previous two statements relating Gaelic to Scottishness. Yet this was substantially lower than Market Research UK's 2003 finding that 66\% of Scots across the country agreed that Gaelic was an important part of "Scottish life" and should be promoted (see section 1.2). A smaller proportion (38\%) agreed with the proposition that Gaelic was 'important to the Highland identity but not the Scottish identity' suggesting either that the language is felt more widely to be part of both, or that it is not generally considered to be part of the Highland identity today.

Compared to the Highland context, a higher proportion - 59\% - of informants at School C felt the Cornish language to be an important part of Cornish identity, with $22 \%$ disagreeing and $19 \%$ uncertain. These data therefore highlight the diacritic significance often attributed to language in the expression of minority identities, even after the minority language in question has generally gone out of use (cf. Williams 2008).

Table 3: Responses to propositions c) and d)

\begin{tabular}{|c|c|c|c|c|c|c|}
\hline Proposition & $\begin{array}{l}\text { Strongly } \\
\text { agree } \\
\%(\mathrm{~N})\end{array}$ & $\begin{array}{l}\text { Agree } \\
\%(\mathrm{~N})\end{array}$ & $\begin{array}{l}\text { Disagree } \\
\%(\mathrm{~N})\end{array}$ & $\begin{array}{l}\text { Strongly } \\
\text { disagree } \\
\%(\mathrm{~N})\end{array}$ & $\begin{array}{l}\text { Don't } \\
\text { know } \\
\%(N)\end{array}$ & $\begin{array}{l}\text { Total } \\
\%(\mathrm{~N})\end{array}$ \\
\hline $\begin{array}{l}\text { c) "The Welsh language is an important } \\
\text { part of the Welsh identity." }\end{array}$ & $\begin{array}{l}25 \\
(41)\end{array}$ & $\begin{array}{l}47 \\
(78)\end{array}$ & $\begin{array}{l}7 \\
(11)\end{array}$ & $\begin{array}{l}8 \\
(13)\end{array}$ & $\begin{array}{l}13 \\
(21)\end{array}$ & $\begin{array}{l}100 \\
(164)\end{array}$ \\
\hline $\begin{array}{l}\text { "The Gaelic language is an important part } \\
\text { of the Scottish identity." }\end{array}$ & $\begin{array}{l}11 \\
(15)\end{array}$ & $\begin{array}{l}36 \\
(48)\end{array}$ & $\begin{array}{l}25 \\
(33)\end{array}$ & $\begin{array}{l}11 \\
(15)\end{array}$ & $\begin{array}{l}17 \\
(22)\end{array}$ & $\begin{array}{l}100 \\
(133)\end{array}$ \\
\hline $\begin{array}{l}\text { "The Cornish language is an important part } \\
\text { of the Cornish identity." }\end{array}$ & $\begin{array}{l}15 \\
(19)\end{array}$ & $\begin{array}{l}44 \\
(53)\end{array}$ & $\begin{array}{l}16 \\
(19)\end{array}$ & $\begin{array}{l}6 \\
(7)\end{array}$ & $\begin{array}{l}19 \\
(23)\end{array}$ & $\begin{array}{l}100 \\
(121)\end{array}$ \\
\hline $\begin{array}{l}\text { d) "The Gaelic language is an important } \\
\text { part of the Highland identity but not the } \\
\text { Scottish identity." }\end{array}$ & $\begin{array}{l}4 \\
(5)\end{array}$ & $\begin{array}{l}34 \\
(45)\end{array}$ & $\begin{array}{l}25 \\
(33)\end{array}$ & $\begin{array}{l}10 \\
(14)\end{array}$ & $\begin{array}{l}27 \\
(36)\end{array}$ & $\begin{array}{l}100 \\
(133)\end{array}$ \\
\hline
\end{tabular}

\subsection{Language abilities}

Understandably, given the stronger position of Welsh in comparison to Gaelic and Cornish (outlined in section 1), proficiency was found to be higher for Welsh than for the other two languages surveyed (see table 4, below). To a significant degree this reflects the greater provision for Welsh language teaching in state schools than for Gaelic or Cornish. 28 students $-17 \%$ of informants - at School A reported fluency in 
the Welsh language, compared to one single instance of fluency in the contexts of Gaelic and Cornish respectively.

Although problems relating to self-reporting leave surveys of language competence open to informants' subjective judgements, the stronger position of Welsh in relation to Gaelic and Cornish is clearly discernible from the data presented in table 4, with $35 \%$ of respondents at School A reporting themselves as able to speak and understand Welsh at least 'fairly well'; in contrast only $10 \%$ reported equivalent competence in Gaelic and 5\% in Cornish. Conversely, a small minority (7\%) of Welsh respondents indicated they could not understand any Welsh, while $31 \%$ of Highland pupils indicated they could not understand Gaelic and 52\% of informants in Cornwall claimed not to understand Cornish.

As far as 'intermediate' abilities are concerned, attitudes to the language presumably play an important role as to informants' choice of response. The semantic distinction between 'I can speak and understand a few basic words' and 'I can speak and understand some' is significant, though in practical terms differences in ability may be marginal (if any). This may also be true of 'higher' level abilities and the choice of reporting an ability to speak the language 'fluently' or 'fairly well'. With regard to reported ability in Welsh, 33\% of informants claimed 'some' ability to speak and understand the language, whereas $25 \%$ claimed to be able to speak and understand 'a few basic words'. The corresponding figures were $46 \%$ and $13 \%$ for ability in Gaelic, and 40\% and 3\% respectively for Cornish.

Table 4: Abilities in Welsh, Gaelic and Cornish

\begin{tabular}{|c|c|c|c|}
\hline Reported level of ability & $\begin{array}{l}\text { Welsh } \\
\%(\mathbf{N})\end{array}$ & $\begin{array}{l}\text { Gaelic } \\
\%(N)\end{array}$ & $\begin{array}{r}\text { Cornish } \\
\%(\mathbf{N})\end{array}$ \\
\hline $\begin{array}{l}\text { I cannot speak or understand } \\
\text { Welsh/Gaelic/Cornish at all }\end{array}$ & $\begin{array}{ll}7 \\
(12)\end{array}$ & $\begin{array}{l}31 \\
(41) \\
\end{array}$ & $52 \quad(63)$ \\
\hline $\begin{array}{l}\text { I can speak and understand a few } \\
\text { basic words of Welsh/Gaelic/Cornish }\end{array}$ & $\begin{array}{l}25 \\
(40)\end{array}$ & $\begin{array}{l}46 \\
(61) \\
\end{array}$ & $40 \quad(48)$ \\
\hline $\begin{array}{l}\text { I can speak and understand some } \\
\text { Welsh/Gaelic/Cornish }\end{array}$ & $\begin{array}{l}33 \\
(54)\end{array}$ & $\begin{array}{l}13 \\
(18) \\
\end{array}$ & (4) \\
\hline $\begin{array}{l}\text { I can speak and understand } \\
\text { Welsh/Gaelic/Cornish fairly well }\end{array}$ & $\begin{array}{l}18 \\
(30)\end{array}$ & $\begin{array}{l}9 \\
(12)\end{array}$ & $\begin{array}{l}4 \\
(5)\end{array}$ \\
\hline $\begin{array}{l}\text { I speak Welsh/Gaelic/Cornish } \\
\text { fluently }\end{array}$ & $\begin{array}{l}17 \\
(28)\end{array}$ & $\begin{array}{l}1 \\
(1)\end{array}$ & (1) \\
\hline Total & $\begin{array}{l}100 \\
(164)\end{array}$ & $\begin{array}{l}100 \\
(133)\end{array}$ & $\begin{array}{l}100 \\
(121)\end{array}$ \\
\hline
\end{tabular}




\subsection{Spearman's rho correlations}

In order to quantify relationships between the three variables of identity, ability and attitudes, the dataset was analysed on software package SPSS. The data were examined using Spearman's rank correlation co-efficient (Spearman's rho) to measure the strength and direction of correlations. The outputs for this statistical test are displayed below in tables 5 and 6; table 5 displays correlation co-efficients for the relationship between identity and ability, and between identity and attitudes. The latter correlation is displayed according to responses given to each of propositions a)c)/d) discussed in section 2.3. Meanwhile table 6 displays Spearman's rho coefficients for the correlation between ability and attitudes (coded as responses to each of these propositions).

\subsubsection{Identity-Ability \& Identity-Attitudes}

\section{Table 5:}

Spearman's rho correlations for Identity-Ability and Identity-Attitudes

\begin{tabular}{|l|r|r|r|r|l|}
\hline Identity & Ability & \multicolumn{1}{|c|}{ a) } & \multicolumn{1}{|l|}{ b) } & c) & d) \\
\hline \multicolumn{7}{|c|}{ School A, Ceredigion } \\
\hline Welsh & $.470^{* *}$ & -.088 & $-.266^{* *}$ & $-.173^{*}$ & N/A \\
\hline British & -.126 & .139 & $.255^{* *}$ & $.232^{* *}$ & N/A \\
\hline European & -.056 & -.011 & .127 & .151 & N/A \\
\hline \multicolumn{7}{|c|}{ School B, West Highlands } \\
\hline Highlander & $.321^{* *}$ & .003 & -.115 & -.02 & .106 \\
\hline Scottish & .147 & .096 & -.005 & $.221^{*}$ & $.175^{*}$ \\
\hline British & -.105 & -.008 & .162 & .07 & .028 \\
\hline European & -.124 & .014 & .107 & .093 & .027 \\
\hline \multicolumn{7}{|c|}{ School C, Cornwall } \\
\hline Cornish & \multicolumn{7}{|c|}{$.257^{* *}$} & -.016 & -.155 & -.171 & N/A \\
\hline English & .041 & -.065 & -.028 & .062 & N/A \\
\hline British & .002 & -.052 & -.173 & .106 & N/A \\
\hline European & $-.186^{*}$ & -.013 & -.095 & .024 & N/A \\
\hline
\end{tabular}

\footnotetext{
**. Correlation is significant at the 0.01 level (2-tailed).
}

*. Correlation is significant at the 0.05 level (2-tailed). 
Significant correlations at the $\mathrm{p}<0.01$ level were found between Welsh identity and Welsh language ability (.470), between Highlander identity and ability in Gaelic (.321), and between Cornish identity and ability in the Cornish language (.257). This can be interpreted as an indication of the degree to which proficiency in the minority (Xish) language can impact on an individual's appreciation of his or her own minority (Xian) identity. In these terms the identity-language link was strongest in Wales and weakest in Cornwall.

Crucially, however, no correlation between identity and language ability was found to be stronger than .5 in any context, suggesting firstly that language is seen as only one of many components of identity, and secondly, that the significance of language in the expression of minority identity is often a question of symbolic value rather than actual competence. At School B the relationship between Scottish identity and ability in Gaelic was below the level of significance, while interestingly, at School C in Cornwall the correlation between European identity and ability in Cornish was significant at the $\mathrm{p}<0.05$ level.

Responses to attitudinal statements were coded as 1 for 'Strongly agree' and 4 for 'Strongly disagree'. Therefore significant negative correlations between Welsh identity and statements b) (-.266), and c) (-.173) reflect support for the Welsh language as a token of identity among respondents who strongly identified themselves as Welsh. Of these, the correlation between Welsh identity and support for statement b) (that "Wales would not really be Wales" without Welsh-speakers) was strongest, being significant at the $\mathrm{p}<0.01$ level. In contrast, positive correlations of 255 and .232 (significant at the $\mathrm{p}<0.01$ level) were found between British identity and opposition to both statements b) and c). Interestingly, this latter finding seems effectively to suggest that respondents who didn't associate closely with Welsh identity didn't think the Welsh language was important even for those who did.

Significant correlations at the $\mathrm{p}<0.05$ level were found between Scottish identity and opposition to statements c) and d) at School B in the Highlands. Therefore respondents who expressed a strong Scottish identity were more likely to oppose to the suggestion that Gaelic is important for either Scottish or Highland identity. No significant correlations were found between identity and attitudes to Cornish among students surveyed at School C. 


\subsubsection{Ability-attitudes}

Table 6: Spearman's rho correlations for Ability-Attitudes

\begin{tabular}{|l|r|r|r|r|}
\hline & \multicolumn{1}{|l|}{ a) } & \multicolumn{1}{l|}{ b) } & \multicolumn{1}{l|}{ c) } & \multicolumn{1}{l|}{ d) } \\
\hline Welsh Ability & .064 & -.122 & $-.155^{*}$ & N/A \\
\hline Gaelic Ability & -.014 & -.165 & -.121 & .022 \\
\hline Cornish Ability & -0.13 & -.137 & -.149 & N/A \\
\hline
\end{tabular}

*. Correlation is significant at the 0.05 level (2-tailed).

The only significant correlation between language ability and language attitudes was found between proficiency in Welsh and support for proposition c), that 'The Welsh language is an important part of the Welsh identity' (-.155). Therefore proficiency is not generally seen to have a significant effect on attitudes to the language as a symbol of identity among students surveyed here.

\section{Conclusions}

The symbolic value attached to Cornish as a component of identity was therefore greater than that assigned to Gaelic as a symbol of either Scottish identity or Highland identity. Perhaps unsurprisingly given its political and demographic position, Welsh was more highly regarded as a symbol of minority identity than either Cornish or Gaelic. Highland identity was not strongly felt at the Highland school surveyed here, nor, surprisingly, was Welsh identity at School A, though as suggested, this may reflect the demographics of the Ceredigion town in which it is located. The symbolic value of language in minority Xian identity was greatest in the Welsh context, followed by the Cornish. The results presented here therefore suggest that Gaelic is not yet considered widely to be an important symbol of Scottish identity among young people. Neither, at the Highland school surveyed here at least, does it seem to be regarded as an important marker of Highland identity, though more research is needed expand on these findings.

\section{Acknowledgements}

The data presented here originally formed the basis of an MA dissertation submitted at the University of Edinburgh in 2008. I am grateful to Prof. William Gillies and Dr. 
Wilson McLeod for their comments and feedback during their supervision of this project.

\section{Notes and references}

\footnotetext{
${ }^{1}$ J. Fishman, Reversing Language Shift: Theoretical and Empirical Foundations of Assistance to Threatened Languages (Clevedon, 1991), p. 394.

${ }^{2}$ Ibid., p. 395; Fishman uses the term 'Xmen' to refer to minority language speakers in his earlier work (such as Reversing Language Shift), but has changed this to the gender-neutral 'Xians' in more recent studies.
}

${ }^{3}$ Ibid., pp. 394-5

${ }^{4}$ Mari Jones, Language Obsolescence and Revitalization: Linguistic Change in Two Sociolinguistically Contrasting Welsh Communities (Oxford, 1998), p. 243.

${ }^{5}$ For analyses that place much less emphasis on the importance of language in identity construction see, for example, C. Eastman 'Language, ethnic identity and change', in John Edwards (ed.), Linguistic Minorities, Policies and Pluralism (London, 1984); R. Rogerson and A. Gloyer 'Gaelic cultural revival or language decline?', in Scottish Geographical Magazine, No. $111,1995$.

${ }^{6}$ S. May, Language and Minority Rights: Ethnicity, Nationalism and the Politics of Language (Harlow, 2001), p. 129.

${ }^{7}$ Ibid., pp. 129-30.

${ }^{8}$ See, for example, R. Hoare 'Linguistic Competence and Regional Identity in Brittany: Attitudes and Perceptions of Identity', in Journal of Multilingual and Multicultural Development, No. 21, 2000; K. King 'Language Ideologies and Heritage Language Education', in International Journal of Bilingual Education and Bilingualism, No. 3, 2000 in the sociolinguistic literature, and S. Macdonald 'The Gaelic Renaissance and Scotland's Identities', in Scottish Affairs, No. 26, 1999; J. Oliver 'Where is Gaelic? Revitalisation, language, culture and identity', in Wilson McLeod (ed.) Revitalising Gaelic in Scotland (Edinburgh, 2006) and K. Glaser Minority Languages and Cultural Diversity in Europe: Gaelic and Sorbian Perspectives (Clevedon, 2007) for sociological and anthropological perspectives.

${ }^{9}$ R. Rogerson and A. Gloyer 'Gaelic cultural revival or language decline?', p. 52.

${ }^{10} \mathrm{~J}$. Oliver 'Where is Gaelic?', p. 7.

${ }^{11}$ R. Hoare 'Linguistic Competence and Regional Identity in Brittany', p.328; A. Cole and C. Williams 'Institutions, Identities and Lesser-used Languages in Wales and Brittany', in Regional and Federal Studies, No. 14, 2004.

${ }^{12}$ S. May 'Accommodating and Resisting Minority Language Policy: The Case of Wales', in International Journal of Bilingual Education and Bilingualism, No. 3, 2000, p. 129.

${ }^{13}$ C. Williams Linguistic minorities in Democratic Context (Basingstoke, 2008), p. 74.

${ }^{14}$ Ibid., p. 88.

${ }^{15}$ Jones, Language Obsolescence and Revitalization, p. 243.

${ }^{16}$ Eastman, 'Language, ethnic identity and change', pp. 267-74.

${ }^{17}$ C. Fowler, 'A Durable Concept: Anthony Smith's concept of "National Identity" and the case of Wales', Paper read at PSA annual conference, 2002, available at <http://www.psa.ac.uk/journals/pdf/ 5/2002/fowler.pdf>

${ }^{18}$ S. Lewis, Tynged yr Iaith (London, 1962).

${ }^{19}$ R.O. Jones 'The Welsh Language: Does it have a future?' in Ronald Black, William Gillies, and Roibeard Ó Maolalaigh (eds.) Celtic Connections: Proceedings of the $10^{\text {th }}$ International Congress of Celtic Studies (East Linton, 1999), p. 431. 
${ }^{20}$ J. Lyon, and N. Ellis, 'Parental attitudes towards the Welsh language', in Journal of Multilingual and Multicultural Development, No. 4, 1991, pp. 239-40.

${ }^{21}$ See <http://www.uoc.es/euromosaic/web/homean/index1.html>.

${ }^{22}$ Cole \& Williams, 'Institutions, Identities and Lesser-used Languages', p. 570.

${ }^{23}$ A. Cole, Beyond devolution and decentralisation (Manchester, 2006), pp. 118-29.

${ }^{24}$ L.P. Newcombe, Social Context and Fluency in L2 Learners: The Case of Wales (Clevedon, 2007), p. 61.

${ }^{25}$ Jones, Language Obsolescence and Revitalization, pp. 244-93.

${ }^{26}$ C. Williams, Linguistic Minorities in Democratic Context (Basingstoke, 2008), p. 253.

${ }^{27}$ Ibid., p. 251.

${ }^{28}$ May, Language and Minority Rights, p. 268.

${ }^{29}$ S. May, 'Accommodating and Resisting Minority Language Policy: The Case of Wales', in International Journal of Bilingual Education and Bilingualism, No. 3, 2000, pp. 101-6.

${ }^{30}$ Ibid., p. 106.

${ }^{31}$ Ibid., pp. 114-6.

${ }^{32}$ Ibid., p. 124.

${ }^{33}$ K. Mackinnon, 'Neighbours in Persistence: Prospects for Gaelic Maintenance in a Globalising English World' in Gordon McCoy with Maolcholaim Scott (eds.) Gaelic Identities: Aithne na nGael (Belfast, 2000), p. 150.

${ }^{34}$ Glaser, Minority Languages and Cultural Diversity in Europe, pp. 63-70.

${ }^{35}$ W. McLeod, 'Gaelic in the New Scotland: Politics, Rhetoric and Public Discourse', in Journal of Ethnopolitics and Minority Issues in Europe, No. 2, 2001.

${ }^{36} \mathrm{~T}$. Caimbeul, 'The Politics of Gaelic Development in Scotland' in Gordon McCoy with Maolcholaim Scott (eds.) Gaelic Identities: Aithne na nGael (Belfast, 2000) p. 65.

${ }^{37}$ McLeod, 'Gaelic in the New Scotland', p. 11.

${ }^{38}$ Williams, Linguistic Minorities in Democratic Context, p. 186.

${ }^{39}$ McLeod, 'Gaelic in the New Scotland', p. 8.

40 Scottish Government 2007. Government plans for Gaelic, available at <http://194.247.95.101/News/This-Week/Speeches/First-Minister/sabmorsot07>.

${ }^{41} \mathrm{See}<\mathrm{http} / / / \mathrm{www} . u o c . e s /$ euromosaic/web/document/gaelic/an/e1/e1.html>.

${ }^{42}$ K. MacKinnon, Gaelic: A Past \& Future Prospect (Edinburgh, 1991), pp. 175-77.

${ }^{43}$ Ibid., pp. 166-7.

${ }^{44}$ Market Research UK/BBC, Attitudes to the Gaelic Language (Glasgow, 2003).

${ }^{45}$ J. Oliver, 'Scottish Gaelic Identities: Contexts and Contingencies', Scottish Affairs, No. 51, 2005; Macdonald, 'The Gaelic Renaissance and Scotland's Identities'.

${ }^{46}$ Oliver, 'Where is Gaelic?', p. 168.

${ }^{47}$ Oliver, 'Where is Gaelic?'; 'Scottish Gaelic Identities'.

${ }^{48}$ Glaser, Languages and Cultural Diversity in Europe, p.72.

${ }^{49}$ Ibid., p. 95.

${ }^{50}$ Williams, Minorities in Democratic Context, p. 189.

${ }^{51}$ Ibid., pp. 186-7; Oliver, 'Where is Gaelic?', p. 158.

${ }^{52}$ Oliver, 'Scottish Gaelic Identities', p. 4;

${ }^{53}$ Macdonald, 'The Gaelic Renaissance and Scotland's Identities', p. 106.

54 K. Glaser, 'Reimagining the Gaelic community: ethnicity, hybridity, politics and communication' in Wilson McLeod (ed.) Revitalisng Gaelic in Scotland (Edinburgh, 2006), p. 171.

${ }_{56}^{55}$ Oliver, 'Scottish Gaelic Identities', pp. 4-9, 'Where is Gaelic?', p. 162.

${ }^{56}$ A. MacCaluim, Reversing Language Shift: The Social Identity and Role of Scottish Gaelic Learners (Belfast 2007), pp. 178-82; Glaser, Languages and Cultural Diversity in Europe, pp. 247-58.

${ }^{57}$ MacCaluim, Reversing Language Shift, p. 94.

${ }^{58}$ Dolly Pentreath, who died in 1777 has often been labelled the 'last native speaker' of Cornish, though many now contend that the language continued to be spoken into the $19^{\text {th }}$ century.

${ }^{59}$ P. Payton, 'The Ideology of Language Revival in Modern Cornwall', in Ronald Black, William Gillies, Roibeard Ó Maolalaigh (eds.) Celtic Connections: Proceedings of the $10^{\text {th }}$ International Congress of CelticStudies (East Linton, 1999), p. 395. 
${ }_{61}^{60}$ Ibid., pp. 411-12.

${ }^{61}$ K. MacKinnon, Independent Study of the Cornish Language, available at $\langle$ http://www.cornwall.gov.uk/index.cfm?articleid=8473>.

${ }^{62}$ Cornwall County Council 2004. Strategy for the Cornish Language, available at <http://www.cornwall.gov.uk/index.cfm?articleid=6080>.

${ }^{63}$ Payton, 'The Ideology of Language Revivall', p. 422.

${ }_{65}^{64}$ MacKinnon, Independent Study.

${ }^{65}$ Ibid.

${ }^{66}$ See $<$ http://www.magakernow.org.uk/index.aspx?articleid=38570>.

${ }^{67}$ M. Wakelin, 'The Cornishness of Cornwall's English', in P. Sture Ureland and George Broderick (eds.) Language Contact in the British Isles: Proceedings of the Eighth International Symposium on Language Contact in Europe, Douglas, Isle of Man, 1988 (Tübingen, 1991), pp. 199-222)

${ }^{68}$ MacKinnon, Independent Study.

${ }^{69}$ Jones, Language Obsolescence and Revitalization, p. 347.

${ }^{70} \mathrm{Ibid}$., p. 337; Jones' meaning here is somewhat unclear. Linguistic and orthographic change is widely acknowledged as inherent to language. The different orthography of Early Modern English, for example, seems not to militate against the work of Shakespeare being often seen as an "emblem" of English cultural identity.

${ }^{71}$ Payton, 'The Ideology of Language Revival' p. 423.

${ }^{72}$ B. Deacon, D. Cole and G. Tregidga, Mebyon Kernow and Cornish Nationalism (Cardiff, 2003), p. 1.

${ }^{73}$ K. MacKinnon, “'As Cornish as possible” - "Not an outcast anymore”: Speakers' and learners' opinions on Cornish', in Philip Payton (ed.) Cornish Studies: Twelve (Exeter, 2004), p. 276.

${ }^{74}$ D. Sayers, Reversing Babel: Declining linguistic diversity and the flawed attempts to protect it, Unpublished PhD thesis (University of Essex, 2009), pp. 265-66.

${ }^{75}$ A. Seward, 'Cornish Rugby and Cultural Identity: A Socio-historical Perspective', in Philip Payton (ed.) Cornish Studies: Five (Exeter, 1997), p. 173.

${ }^{76}$ J. Willett, 'Cornish Identity: Vague Notion or Social Fact', in Philip Payton (ed.) Cornish Studies: Sixteen (Exeter, 2008), pp. 195-200.

${ }^{77}$ See, for example, S. Price, M. Fluck with H. Giles, 'The effects of language of testing on bilingual pre-adolescents' attitudes to Welsh and English', in Journal of Multilingual and Multicultural Development, No. 4, 1983; A. Roberts, 'Parental Attitudes to Gaelic-medium education in the Western Isles of Scotland', Journal of Multilingual and Multicultural Development, No. 12, 1991; N. Coupland, A. Williams and P. Garrett, 'The social meanings of Welsh English: teachers' stereotyped judgements', Journal of Multilingual and Multicultural Development, No. 15, 1994; Hoare, 'Linguistic Competence and Regional Identity in Brittany'; May ‘Accommodating and Resisting Minority Language Policy'.

${ }^{78}$ Note: All percentages are rounded to the nearest percentage point for ease of comparison.

${ }^{79}$ Cole, Beyond devolution and decentralisation, p. 118.

${ }^{80}$ Cited in Cole \& Williams, 'Institutions, Identities and Lesser-used Languages', p. 570. 